Department of Anatomy (Prof. H. Outi) Okayama University Medical School, Okayama, Japan

\title{
The Relationship between Mast Cells and Histamine in Phylogeny with Special Reference to Reptiles and Birds
}

\author{
Kenichi TAKAYA（高屋憲一）
}

Received December 27, 1968

Since histamine was found in mast cells by RILEY and WEST (1952), the role of mast cells and histamine in anaphylactic reactions has been extensively studied, and mast cells have generally been considered histaminocytes.

REITE (1965) measured histamine in 19 different species of animals from fishes to mammals and first proposed the absence of histamine in the mast cells of poikilothermal vertebrates including reptiles, chiefly by the chemical assay of histamine in the organs known to be rich in mast cells and in the whole body of the animals, and concluded that the mast cells of mammals and birds differ in their physiological functions from those of poikilothermal vertebrates.

ARvy (1956) recognized that mast cells of frogs proved to be negative to the mercury-nitrite test of HATEM, the method which was found effective for the detection of histamine in rat mast cells. He was, however, predisposed to the concept that the mast cells of frogs lack the free form of histamine, suggesting the possible presence of histamine in a conjugate form.

Independent of REITE and ARVY, in the course of our study on mast cells in the tongue of the frog, Rana catesbiana (Fujita and TAKaYa, 1966; TAKaya, Fujita and ENDO, 1967), we also came to doubt the presence of histamine in the mast cells of this animal. Using Code's method of histamine extraction followed by bioassay with guinea pig ileum and the histochemical method for histamine with o-phthalaldehyde (JuHLin and SHelley, 1966), we were able to reveal that histamine was lacking in the mast cells of the frog, Rana catesbiana (TAKAYA, FujITA and ENDO, 1967), and later also in those of the newt, Triturus pyrrhogaster Boié (TAKAYA, 1968). In a preliminary survey of several vertebrate species with the above methods we suggested that the association of histamine with mast cells might develop in the phylogenic stages of reptiles and birds.

The present paper deals with the results of our studies with special emphasis on the findings obtained in some species of reptiles and birds.

\section{Materials and Methods}

The animals used were 30 turtles (160-700g) (25 Clemmys japonica and 5 Amyda japonica), 15 hens (1.2-1.5 kg, 4-5 months old), 5 chicks (450-500 g, 40 days old, female), 5 pigeons (200-600 g), 4 carp (Cyprinus carpio), 10 bullfrogs (Rana catesbiana, 250-600 g), 10 newts (Triturus pyrrhogaster Boié, 2.3-3.5 g) which were of both sexes except when indicated. The mesentery and skin of 5 rats (male, 140-170 g) and the blood of one rabbit $(2.0 \mathrm{~kg}$, female, 7 times within $24 \mathrm{hr}$ ) were also examined as controls. 
The histological survey of the mast cell distribution was done by fixing the organs of the above animals, mainly the tongue, muscle, intestine, liver, scales (fish) and comb (hens) in Bouin, Bouin-lead acetate (TAKAYA, 1966), Carnoy, alcoholic formalin $(9: 1)$, and by embedding them in paraffin. Five micron sections were prepared and deparaffinized with xylene. Some sections were hydrated through alcoholic series down to distilled water. They were stained with:

1) Alcoholic thionin ( $0.1 \%$ in $80 \%$ alcohol) for $20 \mathrm{~min}$, washed twice in absolute alcohol, cleared in xylene and mounted on Canada balsam.

2) $0.1 \%$ toluidine blue in distilled water.

3) Dominici's method (RomeIs, 1948)

4) Aluminum-toluidine blue (НЕAтH, 1960).

5) Condensed aldehyde fuchsin (Fujita and Fukuda, 1965) for $20 \mathrm{~min}$ without preoxidation, followed by GoLDNER's trichrome stain. Aldehyde fuchsin of Gomori's recipe (GomoRI, 1950) was also used after permanganate oxidation.

6) $1 \%$ Astra blue (Bloom and Kelly, 1960).

7) Periodic acid Schiff method (McManus, 1961).

The subcutaneous connective tissue, mesentery and scales (fish) were spread on slides, dried in air, fixed in the above fluids and treated thereafter in the same way as the sections. The fish mast cells were also observed by vital staining withe neutral red. Blood smears of all the animals were observed by conventional hematological methods and also by using the fixatives and stains used in the sections. The tissues both rich and poor in mast cells were selected from the above histological study to be processed for histamine assay.

Histamine extraction was performed by CodE's method (CODE and McINTIRE, 1956). Use was made of the mesentery of the hen, pigeon, Clemmys japonica, Amyda japonica, frog and rat; the liver of the hen, pigeon, Clemmys japonica, frog and carp; the intestine of the hen, pigeon, Clemmys japonica, newt and rabbit; the comb of the hen; the tongue of the Clemmys japonica, frog and newt; the skin of the frog and rat; the adrenal of the frog; the air bladder, kidney, liver and scales of the carp; the thymus of the Clemmys japonica. The newt's heart, digestive tract and whole body exclusive of it were assayed for histamine. Homogenates of the tissues and blood ground with sea sand and 10 and $5 \%$ trichloracetic acid were filtered, and the filtrate was boiled for $2 \mathrm{hr}$ with conc. $\mathrm{HCl}$ on a sand bath and then evaporated on a water bath according to the method of CoDE. The dried specimens were dissolved in physiological saline and adjusted to $\mathrm{pH} 7.2$ to be assayed with guinea pig ileum (CoDE and McINTIRE, 1956). Histamine was confirmed by the Neoantergan test. Contaminations which inhibit the contraction of the ileum by histamine were examined by mixing a known quantity of histamine in the extract. The rest of the tissues used for the bioassay was fixed in Carnoy's fluid and the population of mast cells was checked histologically.

The histochemical study for histamine was conducted with the o-phthalaldehyde method (Juhlin and Shelley, 1967; Shelley, ÖHman and Parnes, 1968). A modification was applied in this study to the original test. Drops of $1 \%$ o-phthalaldhyde in p-xylene or ethylbenzene applied directly over the spreads and smears, followed by blotting with filter paper and mounting on tetrahydrofurfuryl alcohol, produced the histamine fluorescence in mast cells similar to that obtained by the original method. Blood of the hen, chick, pigeon. Clemmys japonica, frog, newt and rabbit and the spread preparations of mesentery and subcutaneous connective tissue of the hen, 
pigeon, Clemmys japonica, frog and rat were examined. Spreads of small pieces of newt hearts and frog tongues were also prepared. Observation was made under the fluorescence microscope, Leitz Orthoplan, with a built-in iris diaphragm (OBSOT), and Osram mercury lamp HBO $200 \mathrm{~W}$, BG 38 heat filter $(4 \mathrm{~mm})$, UG 1 exciter filter $(2 \mathrm{~mm}$ ) and one each of ultraviolet eyepiece absorbing filters ( $\mathrm{K} 430$ and green, $2.5 \mathrm{~mm}$ ). A dark field condensor was also used.

After taking photographs, the tetrahydrofurfuryl alcohol was removed from the spreads and smears by blotting with a filter paper; they were then fixed in Carnoy for $3 \mathrm{hr}$, washed in absolute alcohol, stained in alcohol thionin for $20 \mathrm{~min}$, differentiated in $80 \%$ alcohol, washed three times in absolute alcohol, cleared in xylene and mounted on Canada balsam.

Three Clemmys japonica were injected intraperitoneally with $100 \mathrm{mg} l$-histidine (Katayama Chemicals, Ltd.) ( $2.5 \mathrm{ml}$ of $4 \% \mathrm{l}$-histidine in reptilian Ringer solution). After a week the mesentery was studied histochemically for histamine using ophthalaldehyde.

\section{Results}

\section{A. Histological Survey of Mast Cell Distribution}

The tissue mast cells had in general a large cytoplasm teeming with granules which almost covered the nucleus, although there was considerable variation in the concentration of cytoplasmic granules. Blood basophiles were about one fourth of the tissue mast cells in profile size and had coarse round granules not usually observable in mast cells.

Mast cell granules of the animals examined showed identical reactions to stains, i. e., tissue mast cells and blood basophiles exhibited distinct metachromasia in thionin and toluidine blue, stained positively in aldehyde fuchsin either with or without preoxidation, and in Astra blue, reacted weakly positive in the PAS method and were selectively demonstrated in aluminum-toluidine blue. These reactions correspond to those observed in the mature mast cell granules in mammals such as rats and mice (Heath, 1960; Burton, 1964; Combs, Lagunoff and Benditt, 1965) and indicate that mast cell granules contain acidic sulfated mucopolysaccharides.

Aqueous fixatives failed to preserve the granules of mast cells and basophiles of the Clemmys japonica, Amyda japonica, pigeon and carp. The mast cell granules of the frog and newt were relatively resistent to water treatment: some of the granules were preserved even after Zenker-formol fixation. The blood basophiles of all the animals examined seemed to be more fragile to water treatment than the tissue mast cells. Carnoy fixation turned out to be the most effective in preserving the granules of mast cells and basophiles in all the animals examined. The next most effective fixative was Bouin-lead acetate mixture, especially in the Clemmys japonica and Amyda japonica.

\section{Birds}

In hens relatively large numbers of tissue mast cells were found in the mesentery, comb and subcutaneous tissues as was reported in cockrels by Hunt and Hunt (1959). The intestine, both propria mucosae and epithelium (Fig. 1), and comb were the most 

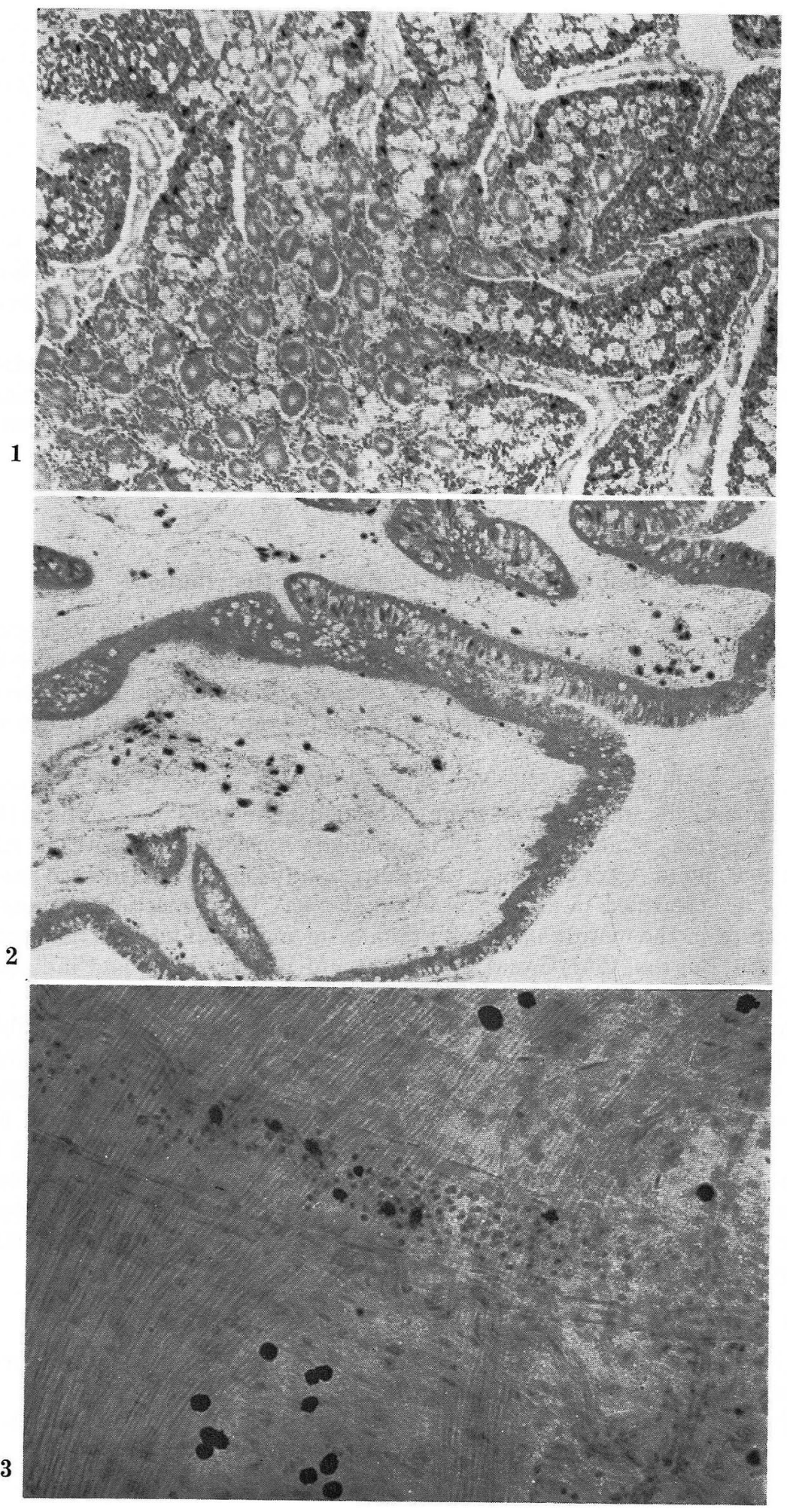
abundant in mast cells among the organs examined. The muscle and liver contained few mast cells except for blood basophiles. The basophiles in the blood counted $5 \%$ of the total leucocytes. According to Magath and Higgins (1934) basophiles range from 0.5 to $1.4 \%$ of the total leucocytes in the chicken. Blood basophiles were about a fourth of the tissue mast cells in profile size and the cytoplasmic granules of the former coarser in size and smaller in number. The reactions of mast cell and basophile granules to the stains used were almost the same as in the turtles.

In the chicks the mast cells and basophiles showed almost the same distribution and stainability as those of the hen.

Pigeons also had the same distribution of mast cells in the comb, mesentery, subcutaneous tissues, intestine, muscle, liver, and blood, although their population in the tissues was by far smaller in comparison to those of hens and chicks. The count of basophiles in the pigeon blood was about $3 \%$ of the total leucocytes. MAGATH and HigGins (1934) gave the count of $4 \%$.

In birds mast cells were accumulated along the sides of the blood vessels though some were found far from the vessels.

\section{Reptiles}

In Clemmys japonica the tongue contained a large number of mast cells beneath and in its mucous membrane (Fig. 2). In the mesentery a relatively large number of mast cells were distributed at random and no such close association with the blood vessels as indicated in mammals and birds (Fig. 11, 15) was observed (Fig. 3). The mesentery and tongue contained a relatively large number of blood basophiles within the vessels: the possible migration of blood basophiles and their transformation into tissue mast cells of matured form with finer granules described by Michel (1923) in the mesentery of the turtles could not be ascertained despite the clear difference in amount and size of granules in both types of cells. The thymus contained abundant mast cells accumulating in the periphery of the lobules (Fig. 4). The size and shape of these cells and the character of the granules resembled those of blood basophiles though these were not present in the vessels of this organ. The liver, muscle and intestine practically lacked tissue mast cells whereas blood basophiles were observable within capillaries in appreciable numbers, as was already reported in the Clemmys leprosa and Testudo mauretanica by Michel (1923). The blood contained abundant basophiles amounting to $60 \%$ of the leucocytes. This corresponds to the results of Michel (1923) who counted $60.5 \%$ in Chrysemys picta and $33 \%$ in Emys europea. The granules of the basophiles and mast cells tended to form vacuoles within each of which a small granule adhered to the membrane. The vacuoles were also dispersed near the disrupted mast cells.

In Amyda japonica the mesentery contained a relatively small number of mast

Fig. 1. The intestine of the hen, fixed in Carnoy, embedded in paraffine, stained in $0.1 \%$ toluidine blue. Mast cells are scattered beneath and within the epithelium. $\quad \times 130$

Fig. 2. Tongue of the Clemmys japonica, fixed in Bouin-lead acetate, embedded in paraffine, staind with Dominici s method. Mast cells, stained intensely violet, are scattered or grouped in the connective tissue under the mucous membrane. Basophiles are also seen within the vessels. $\times 65$

Fig. 3. Mesentery spread of the Clemmys japonica, fixed in Bouin-lead acetate and stained in alcohol thionin. Small basophiles within the capillary and large tissue mast cells outside the vessels are seen. $\times 160$ 


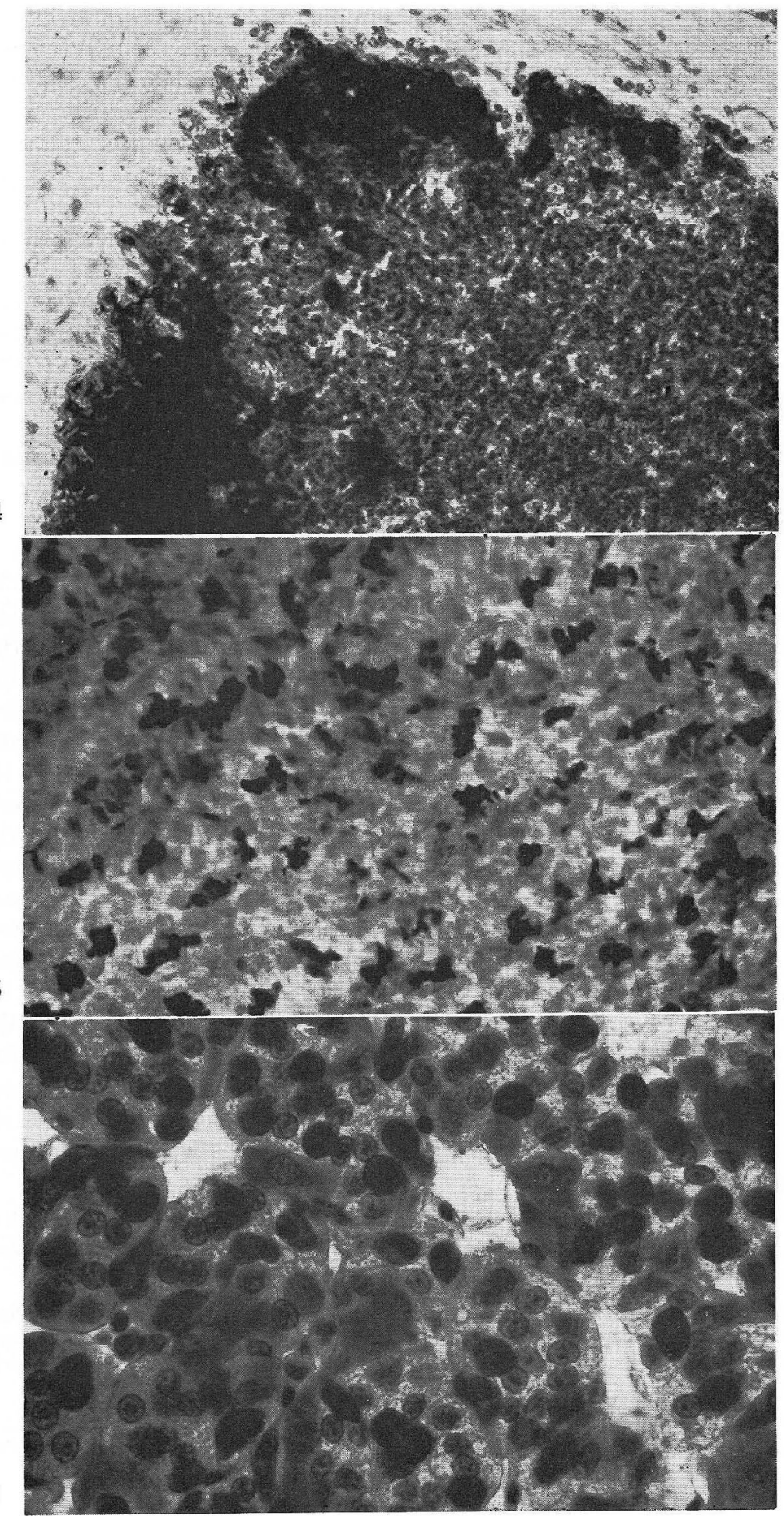


cells, about half that of Clemmys japonica. Mast cells were in no close association with blood vessels. Blood basophiles were also fewer than in the Clemmys japonica and amounted to about $12 \%$ of the total leucocytes. Within the capillaries of the mesentery basophiles were only rarely found.

\section{Amphibians}

As was already reported in the previous paper (TAKAYA, FUJITA and Endo, 1967), the frog, Rana catesbiana, exhibited abundant mast cells in the mesentery (Fig. 5) and tongue and few in the liver and adrenals. The adrenals contained a large number of cells with toluidine blue metachromatic cytoplasmic granules and an eccentric disclike nucleus. This type of cell called "summer cell" or "Stilling cell" (Fig. 6) and known to contain acidophilic and PAS positive granules has been considered a derivative of the mast cell by some authors (see BACHMANN, 1954).

In the tongue and heart of the newt, Triturus pyrrhogaster Boié, a large number of dendritic type mast cells were found beneath the mucous membrane and among muscle bundles respectively. Relatively small numbers of dendritic type mast cells were seen under the mucous membrane of the intestine. The liver contained practically no mast cells of any type. The blood of the newt contained a number of basophiles, about $50 \%$ of the leucocytes as reported by OHuYe and Ocнi (1954).

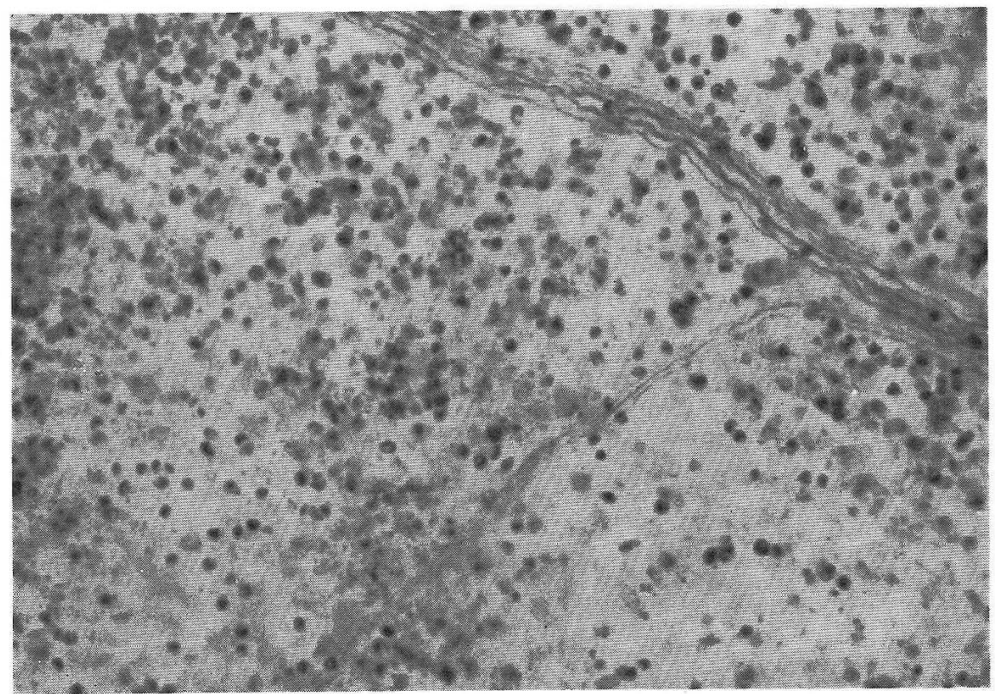

Fig. 7. Spread of the connective tissve supporting the scales of the carp, stained vitally in neutral red, mounted on $0.75 \%$ saline solution. $\Lambda$ bundant mast cells with irregular shape are darkly demonstrated. $\quad \times 200$

Fig. 4. Thymus of the Clemmys japonica, fixed in Carnoy, stained in alcohol thionin. Accumulations of mast cells in the periphery of the lobules are darkly shown; few blood vessels are found. $\times 300$

Fig. 5. Mesentery spread of Rana catesbiana, fixed in Bouin-lead acetate, stained in Dominici's method. Abundant mast cells with irregular cytoplasmic processes were seen. $\quad \times 500$

Fig. 6. Frog adrenals (Rana catesbiana), fixed in Bouin-lead acetate, stained in $0.1 \%$ toluidine blue for 20 min, mounted on Canada balsam. Round summer cells, intensely metachromatic (dark in the picture), are scattered among the cortical cells (light in the picture) and chromaffine cells (grey). $\quad \times 540$ 
The mast cells of the frog and newt showed no close association with the blood vessels. The mast cells and basophiles of these animals principally corresponded in stainability to those of turtles, hens and pigeons.

Table 1. The histamine content and the population of mast cells in the tissues and blood of different animal species

\begin{tabular}{|c|c|c|c|c|c|c|}
\hline \multirow{2}{*}{ Species } & \multirow{2}{*}{$\begin{array}{l}\text { Number, sex, } \\
\text { etc. of } \\
\text { animals used }\end{array}$} & \multirow{2}{*}{ Tissues } & \multirow{2}{*}{$\begin{array}{l}\text { Histamine } \\
\text { content } \\
\mu \mathrm{g} / \mathrm{g}(\mathrm{ml}) \\
\text { wet tissue } \\
\text { (blood) }\end{array}$} & \multicolumn{2}{|c|}{$\begin{array}{l}\text { Cell population in } \\
\text { tissues }\end{array}$} & \multirow{2}{*}{$\begin{array}{l}\text { Percentage of } \\
\text { basophiles } \\
\text { against total } \\
\text { leucocytes }\end{array}$} \\
\hline & & & & $\begin{array}{l}\text { Mast } \\
\text { cells }\end{array}$ & Basophiles & \\
\hline Hen & $\begin{array}{c}5(\text { o }) \\
1.3-1.5 \mathrm{~kg}\end{array}$ & $\begin{array}{l}\text { Mesentery } \\
\text { Intestine } \\
\text { Liver } \\
\text { Comb } \\
\text { Muscle } \\
\text { Blood }\end{array}$ & $\begin{array}{l}1.0-4.3 \\
6.0-26.0 \\
1.1-2.1 \\
1.9=8.1 \\
1.3-3.0 \\
0.73-1.8\end{array}$ & $\begin{array}{l}\text { H } \\
\frac{H}{H} \\
-\end{array}$ & $\begin{array}{l}+ \\
+ \\
+ \\
+ \\
+\end{array}$ & $5 \%$ \\
\hline Pigeon & $\begin{array}{l}1(\hat{o}) \\
600 \mathrm{~g}\end{array}$ & $\begin{array}{l}\text { Mesentery } \\
\text { Insestine } \\
\text { Liver } \\
\text { Muscle } \\
\text { Blood }\end{array}$ & $\begin{array}{l}2.0 \\
3.6 \\
0.9 \\
0.07 \\
0.22\end{array}$ & $\begin{array}{l}+ \\
+ \\
+ \\
-\end{array}$ & $\begin{array}{l}+ \\
+ \\
+ \\
+\end{array}$ & $3 \%$ \\
\hline $\begin{array}{l}\text { Clemmys } \\
\text { japonica }\end{array}$ & $\begin{array}{l}4(\hat{o} 2, \text { o } 2) \\
400-600 \mathrm{~g}\end{array}$ & $\begin{array}{l}\text { Mesentery } \\
\text { Intestine } \\
\text { Liver } \\
\text { Tongue } \\
\text { Muscle } \\
\text { Thymus } \\
\text { Blood }\end{array}$ & $\begin{array}{l}0.69-2.0 \\
0.46-3.0 \\
0.76-1.7 \\
3.4-5.6 \\
0.23-0.55 \\
1.2-1.8 \\
1.2-4.5\end{array}$ & $\begin{array}{l}\frac{H}{E} \\
\frac{H}{H}\end{array}$ & $\begin{array}{l}+ \\
\pm \\
+ \\
+ \\
\pm \\
\pm\end{array}$ & $60 \%$ \\
\hline Amyda japonica & $\begin{array}{l}1(\text { o }) \\
350 \mathrm{~g}\end{array}$ & $\begin{array}{l}\text { Mesentery } \\
\text { Blood }\end{array}$ & $\begin{array}{l}1.7 \\
0.42\end{array}$ & + & + & $12 \%$ \\
\hline Rana catesbiana & $\begin{array}{l}5(\hat{o} 2, \circ 3) \\
250-600 \mathrm{~g}\end{array}$ & $\begin{array}{l}\text { Mesentery } \\
\text { Liver } \\
\text { Tongue } \\
\text { Adrenals } \\
\text { Skin }\end{array}$ & $\begin{array}{l}0.03-0.36 \\
0.03-0.10 \\
0.01-0.06 \\
0.03-0.28 \\
0.14-0.20\end{array}$ & $\begin{array}{l}\frac{}{m} \\
\frac{H}{ \pm} \\
+\end{array}$ & summer cells HI & \\
\hline $\begin{array}{l}\text { Triturus } \\
\text { pyrrhogaster }\end{array}$ & $\begin{array}{r}6(\hat{o} 3, \hat{o} 3) \\
2.3-3.5 \mathrm{~g}\end{array}$ & $\begin{array}{l}\text { Heart } \\
\text { Tongue } \\
\text { Liver } \\
\text { Digestive tract } \\
\text { Whole body } \\
\text { except diges- } \\
\text { tive tract } \\
\text { Blood }\end{array}$ & $\begin{array}{l}0.13 \\
0.20 \\
1.01 \\
0.10-1.10 \\
0.049-0.054 \\
\\
0.04\end{array}$ & $\frac{H}{+}$ & & $50 \%$ \\
\hline Cyprinus carpio & $\begin{array}{l}2(\text { q }) \\
120 \mathrm{~g}\end{array}$ & $\begin{array}{l}\text { Air bladder } \\
\text { Liver } \\
\text { Kidney } \\
\text { Stomach } \\
\text { Scales }\end{array}$ & $\begin{array}{l}0 \\
0 \\
0 \\
0 \\
0-0.015\end{array}$ & $\begin{array}{l}\frac{H}{1} \\
- \\
+ \\
+t\end{array}$ & & \\
\hline Rat & $\begin{array}{c}4(\hat{o}) \\
140-170 \mathrm{~g}\end{array}$ & $\begin{array}{l}\text { Mesentery } \\
\text { Abdominal skin }\end{array}$ & $\begin{array}{l}20.4-29.2 \\
26.7-32.6\end{array}$ & H & & \\
\hline Rabbit & $\begin{array}{l}1(\text { 우 }) \\
2.0 \mathrm{~kg}\end{array}$ & $\begin{array}{l}\text { Blood } \\
\text { (7 times a day) }\end{array}$ & $4.6-5.7$ & & & $9 \%$ \\
\hline
\end{tabular}




\section{Fishes}

Although the preservation of mast cells was very difficult in the carp, Cyprinus carpio, by ordinary fixatives, vital staining in neutral red clearly showed the accumulation of mast cells in the spreads of the air bladder, scales (Fig. 7) and mesentery of the carp. They showed no intimate relation to blood vessels. They were also disclosed by Carnoy fixation and alcohol thionin stain. The mast cell granules were orthochromatic in toluidine blue in Bouin-lead acetate fixation but no conclusive results could be obtained by using other stains because of their poor preservation.

\section{B. Histamine Content of the Tissues}

Table 1 shows the histamine content of various tissues together with the population of mast cells in the hen, pigeon, Clemmys japonica, Amyda japonica and carp. The values for the tissues of the newt, frog, rabbit and rat are also included for comparison, some of which were reported previously (TAKAYA, FujiTA and ENDO, 1967; TAKAYA 1968). The histamine content of several tissues rich in mast cells of some species is shown in Figure 8 and that of the blood in several species in Figure 9.

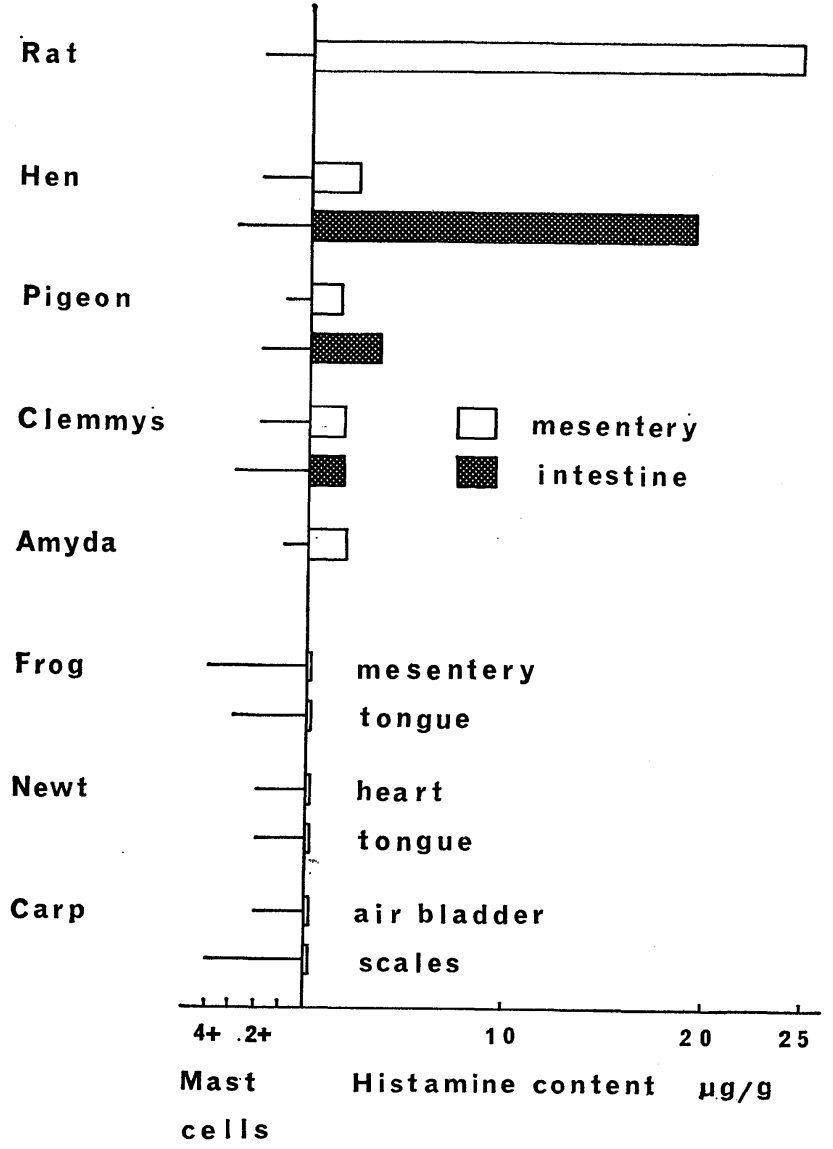

Fig. 8. Mean values of histamine content (on the right side) and population of mast cells (on the left side) in the representative tissues. 


\section{Birds}

The values of histamine in various tissues of the hen obtained in the present study were by far lower than in the reports by MisRahy (1946) and BEAUMARIAGE and LECONTE (1956). Histamine values in the small intestine, liver and red muscle of the hen were 76.3, 9.7 and $9.1 \mu \mathrm{g} / \mathrm{g}$ respectively by MisRAHY (1946) and that in the liver of the hen was $6 \mu \mathrm{g} / \mathrm{g}$ by Beaumariage and LeConte (1956). The difference in the values given by these authors from ours is probably due partly to the difference in the method employed and the strains examined.

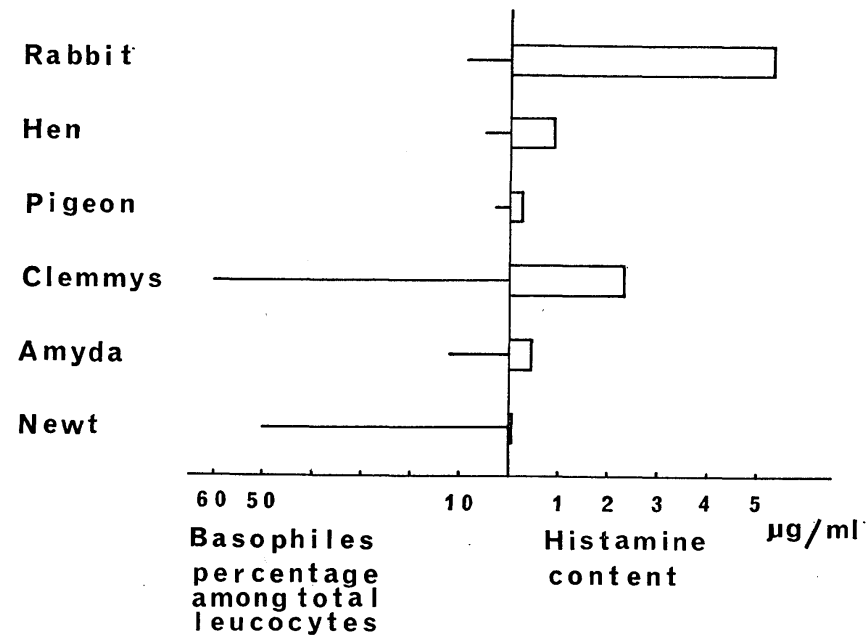

Fig. 9. Mean values of histamine content in the blood of 5 species are shown on the right side and the percentage of basophiles among total leucocytes on the left.

As is seen in Table 1 the high value of histamine in the intestine and comb can be adequately correlated with the rich number of mast cells in these organs in addition to the non-mast cell histamine in the former. A considerable, though much lower, amount of histamine detected in the liver and muscle which were lacking in mast cells is probably due to the contamination of materials with histamine-like activity because Neoantergan suppressed only $60-70 \%$ of the contraction in the guinea pig ileum induced by the extract. The blood contained much histamine, comparable to that of the rabbit $(4.6-5.7 \mu \mathrm{g} / \mathrm{ml}$ in the present study, $2.20-3.51 \mu \mathrm{g} / \mathrm{ml}$ by CoDE, DEw and HigGins, 1953 ; and $0.40-3.15 \mu \mathrm{g} / \mathrm{ml}$ by Gra ̃ A, 1945) and turtles. It can be safely concluded that mast cells and blood basophiles of the hen contain histamine.

Although only one pigeon was examined, the histamine value in both the organs and blood indicated that there was histamine both in the mast cells and blood basophiles. The occurrence of histamine in these cells of the hen and pigeon was also confirmed by histamine histochemistry with o-phthalaldehyde (vide infra).

\section{Reptiles}

In Clemmys japonica the blood containing abundant basophiles as mentioned above showed about 50 times more histamine than in newt blood. The value was almost comparable to that of rabbit blood which contains about $9 \%$ basophiles among 
leucocytes ( $6.7 \%$ by CASEY et al., 1936). The tongue contained much histamine and also a large number of tissue mast cells and basophiles. It was peculiar to this species that the histamine values were not essentially different among the liver, intestine and mesentery. The liver and intestine of turtles had only basophiles while the mesentery contained a large number of tissue mast cells besides the blood basophiles within the capilaries. The blood basophiles of the Clemmys japonica, if one accepts that they contain a considerable amount of histamine, may account for the histamine values counted in these tissues. It seems then as if tissue mast cells contained either none or only a trace of histamine as was the case in amphibia and fishes. Although the tongue of the turtle contained about 2-3 times as much histamine as both organs mentioned above, this hypothesis could not be denied if one takes into account that the tongue is especially rich in blood. Histamine content of mast cells of Clemmys japonica will be further treated in the histochemistry for histamine with o-phthalaldehyde.

In Amyda japonica the mesentery contained as much histamine as in Clemmys japonica, while the blood showed about one fourth the histamine as found in Clemmys japonica and about $12 \%$ basophiles among the leucocytes. Blood basophiles of the Amyda japonica appear to contain histamine but it is inconclusive whether the tissue mast cells of this animal contain histamine.

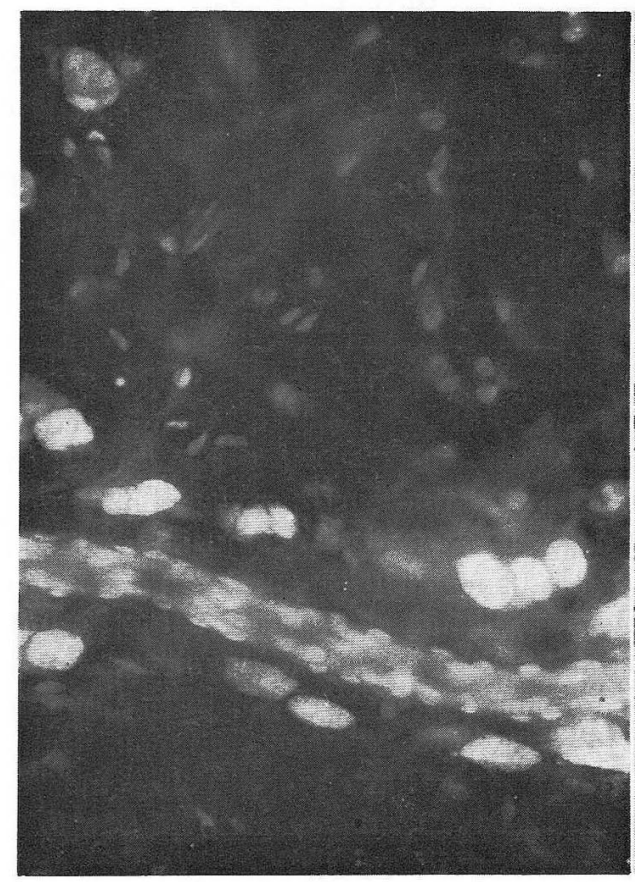

10

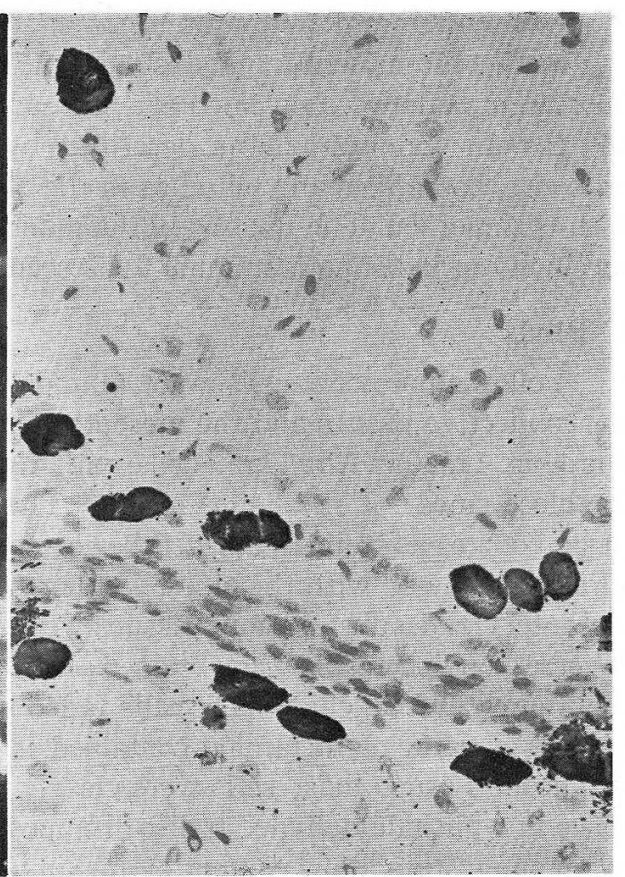

11

Fig. 10. A spread of rat mesentery, stained with o-phthalaldehyde in p-xylene and mounted on tetrahydrofurfuryl alcohol and observed under the fluorescence microscope. Mast cells fluoresced in yellow, while other cells in white. $\times 270$

Fig. 11. The same spread as in Figure 11 is shown after removal of tetrahydrofurfuryl alcohol, fixation in Carnoy and staining in alcohol thionin for $20 \mathrm{~min}$. Mast cells were selectively disclosed. 


\section{Amphibia}

In both the frog and newt a very small amount of histamine, identified as such by the Neoantergan test, was revealed in several organs both rich and poor in mast cells. When a known quantity of histamine was added in the specimen extracted from the frog liver, the contraction of the guinea pig ileum induced by the extract was about 20-30\% less than that expected, which indicated contamination of the inhibiting substances in the extract. On the contrary, very little inhibiting substances were revealed in the extracts from the tongue, mesentery and adrenals of this animal. Frog adrenals showed as low a histamine value as the mast cell free liver. Mast cells of the newt and frog as well as the summer cells of the frog adrenals, therefore, are considered to lack histamine, as was partly reported previously (TAKAYA, FujiTA and ENDO, 1967; TAKAyA, 1968). Newt blood which has many basophiles, about $50 \%$ of its leucocytes, gave only a trace value of histamine.

\section{Fishes}

Histamine content of the carp, Cyprinus carpio, was almost nil in the scales, kidney, testis and air bladder, some of which contained a large number of mast cells.

\section{Histochemistry for Histamine with o-Phthaladehyde}

In the rat mesentery and subcutaneous connective tissues a large number of fluorescent cells were revealed and were identified as mast cells after Carnoy fixation and thionin staining as was described by Juhlin and Shelley (1967) (Fig. 10, 11). Likewise, basophiles and platelets in the blood smear of the rabbit were also revealed with this method. The use of o-phthalaldehyde in ethylbenzene gave better results in specificity of inducing histamine fluorescence than that in $\mathrm{p}$-xylene.

\section{Birds}

Yellow fluorescent cells were abundantly observed in the spreads of subcutaneous connective tissues and the mesentery of hens by the method with o-phthalaldehyde (Fig. 12,15). Abundant cells with the same fluorescence were also revealed in the blood smear of the hen (Fig. 13). They were identified as blood basophiles and thrombocytes as well as other types of cells which are to be elucidated in the same spreads restained with thionin. The fluorescent cells found in the preparations of the mesentery and subcutaneous tissues were identified as tissue mast cells (Fig. 14, 15). A corresponding result was obtained also in the mesentery spreads of the chick, though the fluorescence in chick mast cells faded more rapidly than in the hen probably due to a lower value of histamine contained in the individual mast cells. In pigeon subcutaneous tissues mast cells were clearly recognized by their typical yellow fluorescence in o-phthalaldehyde. It also disappeared readily after ultraviolet light exposure, again suggesting a low content of histamine in the individual mast cells. This view may be supported by the observation of the present author on the rapidly disappearing fluorescence in guinea pig mast cells in contrast to the long preservation of the fluorescence in rat mast cells which are known to contain more histamine than the former.

\section{Reptiles}

In Clemmys japonica blood basophiles in smears fluoresced after the o-phthalaldehyde treatment and were confirmed with thionin stain (Fig. 16,17). Some of the 
granules were round and compact, whilc others were vesicles with a spot adhering to the vesicle membrane both of which fluoresced with o-phthalaldehyde method. Outside the capillariies in the mesentery spreads of the Clemmys japonica, tissue mast cells showed vesicular cytoplasm emitting an orange yellow fluorescence which was so faint that they were scarcely recognizable. With Carnoy fixation and thionin stain of the same spread, the yellow fluorescent cells in the capillaries and the vesicular cells

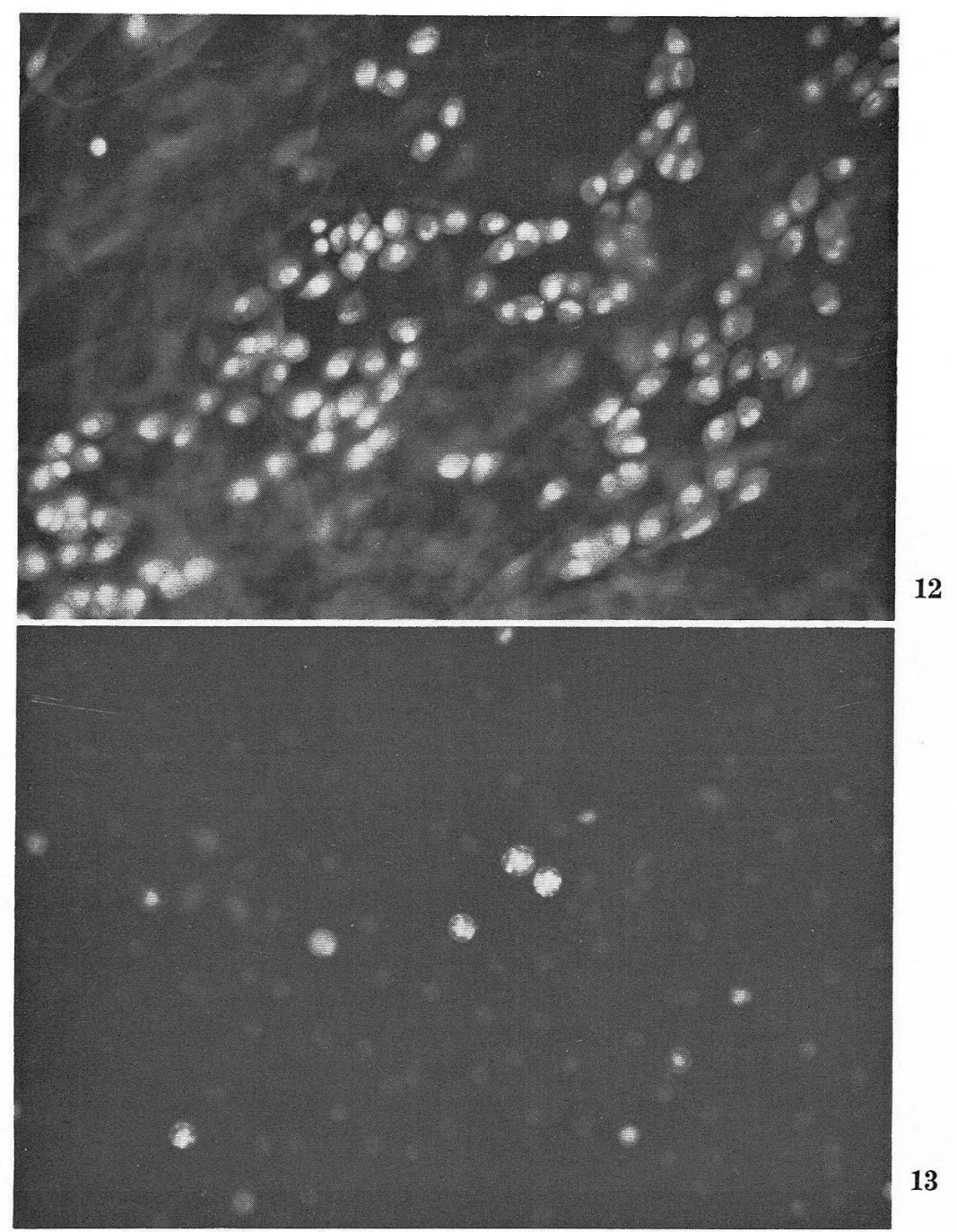

Fig. 12. Subcutaneous connecsive tissue spread of the hen, stained with ophthalaldehyde in ethylbenzene, observed under the fluorescence microscope. $\times 300$

Fig. 13. Blood smear of the hen, stained with o-phthalaldehyde in ethylbenzene, observed under the fluorescence microscope. The larger fluorescent cells were basophiles and the smaller ones thrombocytes. The fluorescence of both types of cells was yellow in color. $\times 450$ 
outside the capillaries were identified as blood basophiles and tissue mast cells respectively. In normal Clemmys japonica the number of the fluorescent tissue mast cells turned out, by restaining procedure, to be smaller than that of the tissue mast cells stained in thionin. On the other hand, those corresponding to blood basophiles were almost as many as the whole blood basophiles recognized in the thionin staining. Cells with whitish yellow fluorescence were also revealed in the mesentery treated with ophthalaldehyde and they were not autofluorescent cells. The nature of these cells is not known.

The mesentery of $l$-histidine injected Clemmys japonica showed an increase in the number of cells with yellow fluorescence, typical of histamine, and in the intensity of the fluorescence of these cells (Fig. 18, 19). This probably indicates that the mast cells of the Clemmys japonica, though some contain only indetectable amounts of histamine, have the ability to synthesize it from $l$-histidine.

\section{Fishes}

In the spread preparations of the carp scales, recognized as representative organs rich in mast cells (Michel, 1923; Arvy, 1955) and also confirmed as such in the present study, no fluorescent cells which could be identified as mast cells were found.

In all the species examined the autofluorescent cells were recognized in various

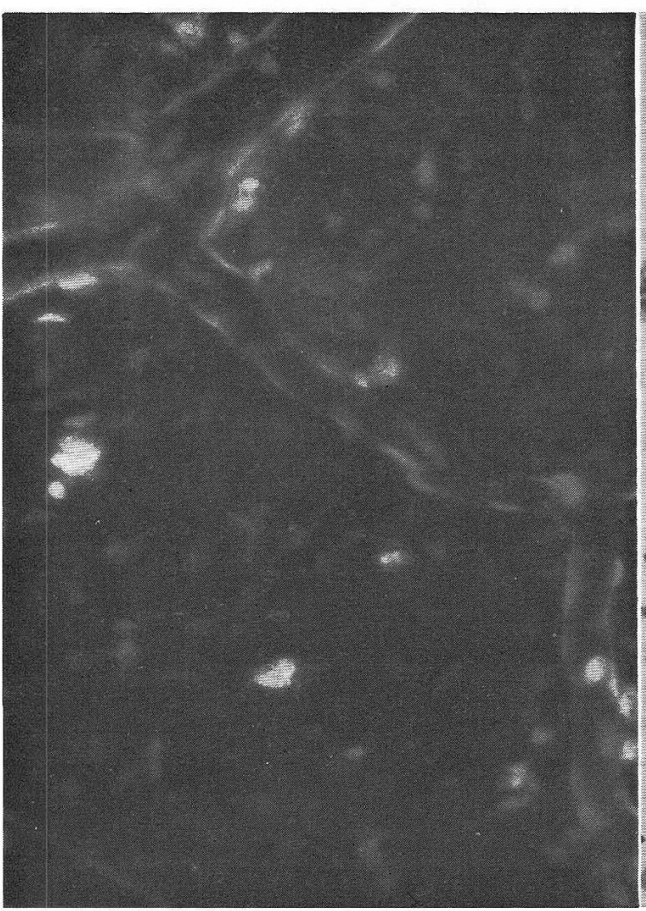

14

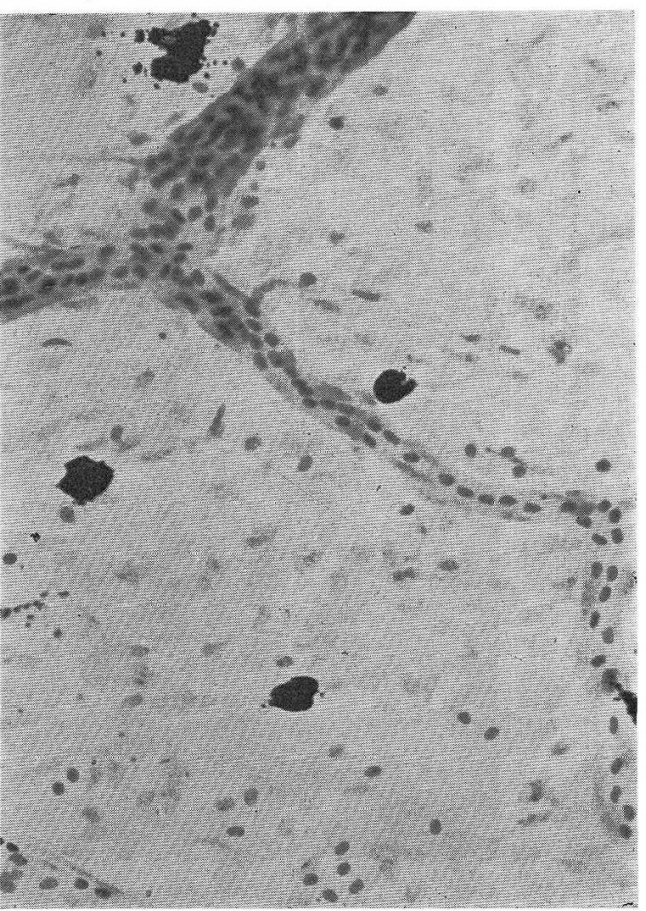

15

Fig. 14. A spread of the mesentery of the hen, stained with o-phthalaldehyde in p-xylene and mounted on tetrahydrofurfuryl alcohol and observed under the fluorescence microscope. $\quad \times 410$

Fig. 15. The same spread as in Figure 15 is shown after removal of terahydrofurfuryl alcohol, fixation in Carnoy and staining in alcohol thionin for $20 \mathrm{~min} . \quad \times 450$ 
numbers and identified by omitting o-phthalaldehyde in the procedure; or observing the spreads and smears on a saline mount without treatment.

\section{Discussion}

REITE (1965) who measured the histamine content of tissues in a variety of animal species did not scrutinize the mast cell population in individual tissues used for histamine assay, although the variations in the mast cell population in different animals even within the same species had long been known (Michel, 1923). ReITE examined the histamine content of only a few representative tissues such as the blood and mesentery of each animal. He used mainly the chemical method of histamine assay which affords a simple and rapid estimation but is inferior in specificity to bioassay. From his results REITE deducted that the histamine rich mast cells of birds and mammals were different in physiological functions from the histamine poor mast cells of lower vertebrates inclusive of reptiles.

HunT and Hunt (1959) supposed the absence of histamine in tissue mast cells of cockrels on the basis of the lack of response to intravenous administration of a histamine liberator, compound 48/80. REITE (1965) reported a high histamine content in the avian skin and concluded that the avian mast cells are rather similar to those of mammals in histamine content and physiological functions. The present results clearly indicated the presence of histamine both in the mast cells and blood basophiles of birds: hens, chicks and pigeons.

As for reptiles, Hatai, Hashimoto and Ubukata (1962) isolated blood basophiles of the Clemmys japonica from which they assayed a "high amount of histamine" although no figurative value was given. Neither did they mention the histamine content of tissue mast cells in this animal. ReITE (1965) investigated 4 species of reptiles, including the tortoise, and detected only a small amount of histamine. He thus considered reptilian mast cells more akin to those of fishes and amphibians. The present bioassay and histochemical study revealed a high amount of histamine in the blood basophiles of turtles, comparable to that of rabbit basophiles. It was also indicated that the tissue mast cells of Clemmys japonica contain histamine in various amounts and they are able to synthesize histamine from $l$-histidine.

Although the bioassay results of the tissues of Clemmys japonica and Amyda japonica were inconclusive about the presence of histamine in mast cells, fluorescent cells, small in number, could be identified in the mesentery and subcutaneous tissues of normal Clemmys japonica. No fluorescent mast cells could be found in the mesentery of Amyda japonica but a further study is needed as only one specimen was examined. Attempts to replace the blood of Clemmys japonica with reptilian Ringer solution in order to make the organs free of blood basophiles so that the histamine in the tissue mast cells and in the blood basophiles could be analysed differentially proved unsuccessful; in all the specimens examined capillary blood persisted even after long perfusion with the Ringer solution. Further studies are also required to elucidate the histamine synthesis in the mast cells of turtles by observing the augumentation of 0 -phthalaldehyde fluorescence of mast cells after $l$-histidine administration and the bioassay confirmation of the histamine content.

It is apparent from the present study that the mast cells and basophiles of turtles and birds as well as the thrombocytes of birds contain histamine and that the 


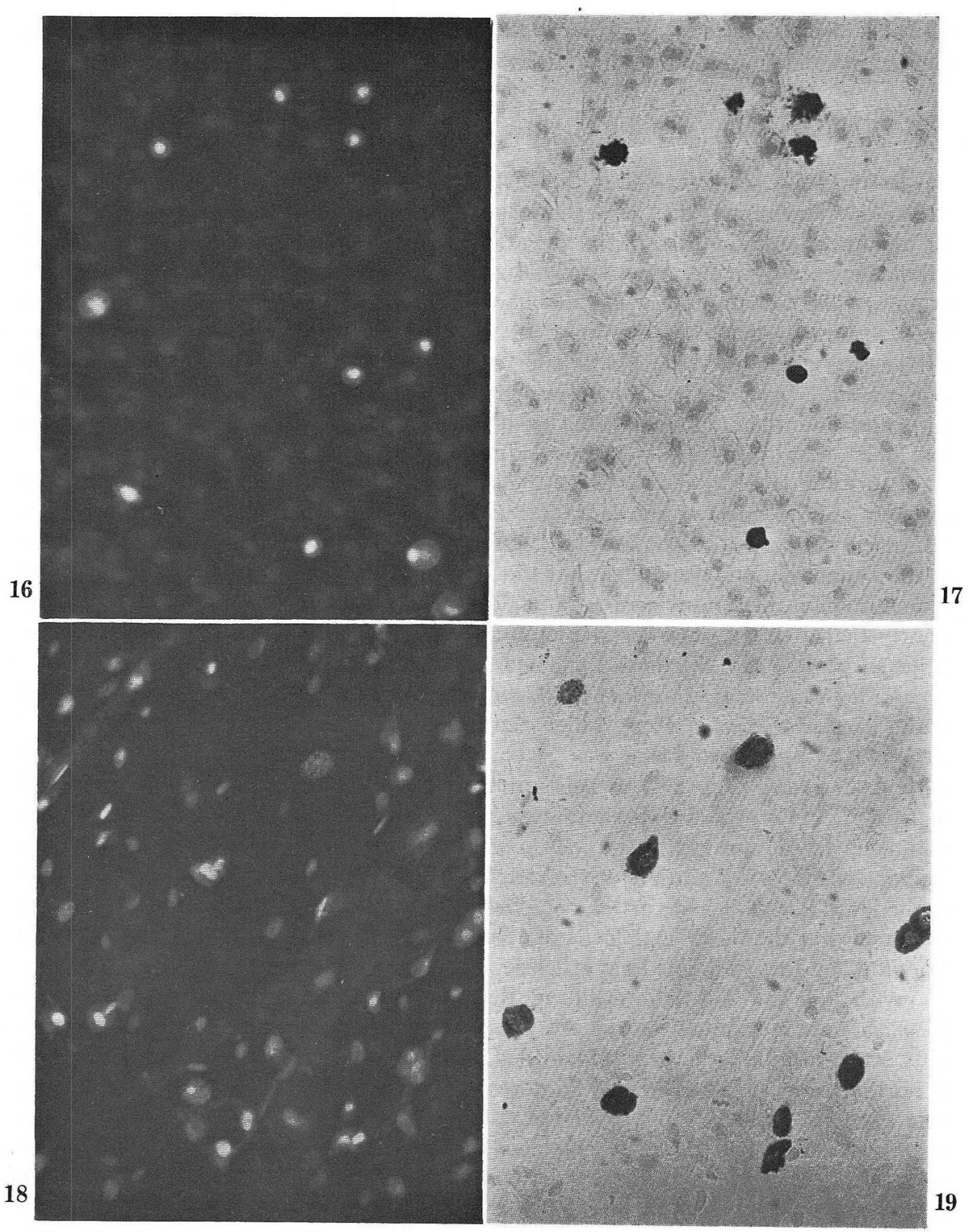

Fig. 16. Blood smear of the Clemmys japonica, stained with o-phthalaldehyde in cthylbenzene and mounted on tetrahydrofurfuryl alcohol and observed under the fluorescence microscope. $\times 426$

Fig. 17. The same smear as in Figure 16 is shown after removal of tetrahydrofurfuryl alcohol, fixation in Carnoy and staining in alcohol thionin for $20 \mathrm{~min}$. The basophiles exhibited yellow fluorescence, and the eosinophiles which have a larger cytoplasm than the basophiles and an eccentric nucleus emitted whitish blue fluorescence. $\times 426$ 
histamine contents in the cells of turtles and birds, are intermediate between the values in mammals and in amphibians and fishes.

As KAHLson and Rosengren (1968) indicated, little attention has been paid to the blood basophiles which were found also to contain histamine by many authors. The species examined, however, were restricted to man and several mammals such as dog and rabbit. Presence of histamine in the blood basophiles of reptiles and its absence in those of the newt shown in this study suggest the close smimilarity of the blood basophiles to tissue mast cells concerning the appearance of histamine in their granules in phylogeny, although the meaning of the histamine content of the other blood cells such as thrombocytes are unknown.

BuRTON (1964) histochemically studied the postnatal development of rat mast cells. In conjunction with the animal's development he found an increase in the number of cells with granules stained red in toluidine blue. In immature animals predominating were the cells with granules, stained blue in Alcian blue-safranin combination, PAS positive and orthochromatic in toluidine blue. The change in the stainability of mast cell granules, especially in the PAS method, was explained by the fact that heparin in the granules was converted from the less-sulfated form. By combining various histochemical methods with the bromaniline test for histamine (Lagunoff, Phillips and Benditt, 1960), Combs, Lagunoff and Benditt (1965) showed that histamine appeared after the maturation of rat mast cells, i.e. after the granules became PAS negative, and stained red in Alcian blue-safranin and metachromatic in toluidine blue. Although conclusive results could not be obtained in the present study with Alcian blue-safranin stain, because the fixation in $10 \%$ formalin did not preserve the mast cell granules of birds and lower vertebrates, toluidine blue metachromasia and a negative reaction in the PAS method recognized in the specimens fixed in Carnoy and Bouin-lead acetate indicated that mast cells in the adult lower vertebrates and birds rather resembled those of the mature form of rat mast cells. The theory that ontogeny recapitulates phylogeny is valid as far as that the appearance of histamine in mast cells is phylogenetically as well as ontogenetically retarded to the formation of their granules but it appears inapplicable to such a detail as the relationship between the change in chemical nature of mucopolysaccharides in the granules and the appearance of histamine in them.

\section{Summary}

Various animals from fish to mammals, especially the carp (Cyprinus carpio), turtles (Clemmys japonica and Amyda japonica) and birds (hens, chicks and pigeons) were studied with special reference to the phylogenic relation between mast cells and histamine. Histamine assay (histamine extraction with Code's method and bioassay with guinea pig ileum) in different tissues was combined with a histological study on their mast cell population, and histamine histochemistry with o-phthalaldehyde in p-xylene or ethylbenzene was performed on the spreads and smears.

Fig. 18. A mesentery spread of the Clemmys japonica, a week after an intraperitoneal injection of $100 \mathrm{mg} l$-histidine, stained with o-phthaldehyde in ethylbenzene, mounted on tetrahydrofurfuryl alchol and observed under the fluorescence microscope. $\times 295$

Fig. 19. The same spread as in Figure 18 is shown after removal of tetrahydrofurfuryl alcohol, fixation in Carnoy and staining in alcohol thionin. The mast cells were filled with the granules which emitted yellow orange fiuorescence. The other cells fluoresced in white. $\times 270$ 
Bioassay revealed an appreciable amount of histamine in tissues rich in mast cells and in the blood of the hen, chick and pigeon, the mast cells, basophiles, thrombocytes and other unknown types of cell distinctly fluoresced with the o-phthalaldehyde method.

The blood of the turtles was shown by bioassay to contain a considerable amount of histamine and their blood basophiles exhibited distinct yellow fluorescence. Though the result of the histamine bioassay of turtle tissues was equivocal and only a few mast cells fluoresced, the injection of $l$-histidine in Clemmys japonica caused an increase in the number of fluorescent mast cells and an increase in the intensity of their fluorescence, suggesting an ability of mast cells to synthesize histamine.

Several tissues of the carp contained only a trace of histamine and the mast cells did not fluoresce. Taking into consideration the similar results in the frog (TAKAYA, FUJITA and ENDO, 1967) and newt (TAKAYA, 1968), it is likely that histamine firstly appears in mast cells at the level of reptiles in phylogeny. The amount of histamine in mast cells and basophiles gradually increases in reptiles, birds and mammals.

Several histochemical tests for mucopolysaccharides in the granules of mast cells and basophiles showed that the mast cells of all the animals examined, except for the carp whose mast cells were hardly preserved, contained acidic sulfated mucopolysaccharides. The solbuility of the granules in water varied conspicuously from species to species.

Acknowledgement. The present study was suggested and directed by Dr. Tsuneo Fujita, Professor of Anatomy at the Niigata University School of Medicine, when he was in the Department of Anatomy at Okayama University Medical School. Sincere thanks are due to Dr. Hiromu Outr, the Director of the named department, for his encouragement and critical reading of the manuscript. The author also expresses his gratitude to Dr. Hidemasa Yamasaki, Director of the Department of Pharmacology of Okayama University Medical School, for his valuable advice and kind support. The measurement of histamine was enabled by the excellent technique provided by Dr. Koiti ENDo in the Pharmacology Department.

\section{系統発生的に見た肥満細胞とヒスタミンの関係一とくに鳥類, 爬虫類 について (内容自抄)}

魚類から哺乳類に至る種々の動物，とくにコイ，イシガメ，スッポン，ニワトリ，八 卜を用いて 肥満細胞や好塩基球とヒスタミンの関係を系統発生的にしらべた.

ヒスタミンは血液や諸臓器 (小腸, 肝, 舌, 腸間膜など) からCode 法によって抽出し, モ ルモットの回腸を用いて bioassay を行なった。肥満細胞と好塩基球の分布密度は 切片 や伸展標本で組織学的にしらべた，好塩基球は血液の全白血球中の百分率を求めた。ま た主に腸間膜や皮下組織の伸展標本を用いて, 細胞内のヒスタミンの存在を o-phthalaldehyde 法 (JUHLIN と SHELley) により螢光顕微鏡でしらべた.

鳥類（ニワトリとそのひな，ハト）では血液や小腸，腸間膜（好塩基球や肥満細胞を 多く含む) から多量のヒスタミンが抽出される。o-phthalaldehyde 法では血液の好塩基 球, 栓球と他の若干の種類未定の細胞, および組織肥満細胞が ヒスタミンに特異な黄色 の䖝光を示した.

カメ（イシガメとスッポン）の血液は多数の好塩基球をもつ. 血液の bioassay で多 
量のヒスタミンが証明され，o-phthaladehyde 法でも好塩基球にヒスタミンの螢光が見 られた，肥満細胞については 組織のヒスタミンの biassay では決定的な結論は得られ なかったが，o-phthalaldehyde 法により，少数ながら肥満細胞に特異螢光が見られた。 イシガメの腹腔内に $l$-histidine を投与して 1 週間のちに腸間膜と皮下組織をしらべる と，螢光を発する肥満細胞の数が増し，またその螢光の強さも増した。これは肥満細胞 が少なくともヒスタミン合成能力をもつことを示す.

コイの肥満細胞には bioassay でも螢光法でもヒスタミンは証明できなかった.

私達がさきに発表したカエルとイモリについての結果をも考えあわせると，肥満細胞 と好塩基球のヒスタミンは爬虫類の段階で始めてあらわれ, 鳥類から哺乳類へと次第に その量が増加してゆくて見てよい.

肥満細胞顆粒の多糖類に関する種々の組織化学的検索の結果は, 両棲類以上ですでに 哺乳類のとれとほとえぞ变りがない。ただし水に対する溶解性は種により著しく異った.

\section{References}

Arvy, L. : Les labrocytes (Mastzellen). Rev. haematol. 10: 55-94 (1955).

: Particularités histologiques des labrocytes chez quelques batraciens. C. r. Assoc. Anat. 42 : Réunion, 217-223 (1956).

Bachmann, R. : Die Nebenniere. In: Möllendorffs Handbuch der mikroskopischen Anatomie des Menschen. VI. Berlin-Göttingen-Heidelberg, Springer, 1954 (p. 1-952).

Beaumariage, M. L. and J. LeConte: Teneure en histamine de quelques organes du coq. C. $r$. Soc. Biol. Paris 150: 227-229 (1956).

Bloom, G. and W. Kelly : The copper phthalocyanine dye "Astra blau" and its staining properties, especially staining mast cells. Histochemie $2: 48-57$ (1960).

Burton, A. L. : Histochemical studies on developing mast cells. Anat. Rec. 150 : 265-269 (1964).

Casey, A. E., P. D. Rosahn, C. Hu and L. Pearce: The hemocytological constitution of adult male rabbits from fifteen standard breeds. J. exp. Med. 64 : 453-469 (1936).

Code, C. F., P. B. Dew and G. M. Higgins : The relationship of the adrenal gland to concetration of histamine and number of leucocytes in the blood of rabbits. J. Physiol. (London) 121 : 487491 (1953).

Code, C. F. and F. C. McIntire : Quantative determination of histamine. In : (ed. by) D. Glick : Method of Biochemical Analysis. New York, Interscience Publishers, 1956 (Vol. 3, p. 49-95).

Combs, J. W., D. Lagunoff and E. P. Benditt : Differentiation and proliferation of embryonic mast cells of the rat. J. Cell Biol. 25 : 577-592 (1965).

Fujita, T. and Y. Fukuda : Aldehyde fuchsin-light green stain of the subcutaneous tissue spread of the rat: A new technique for student's laboratory course (Japanese with English abst.). Acta anat. nippon. 35 : 714-718 (1960).

Fujita, T. and K. Takaya : Mast cells in the lymphatics of frog tongue. Z. Zellforsch. 75 : 160165 (1966).

Gomori, G. : A new stain for elastic tissue. Amer. J. clin. Pathol. 20 : 665-666 (1950).

Graña, A. and M. Rocha e Silva : Effects of hydatic fluid on histamine content of rabbit blood. Amer. J. Physiol. 143 : 314-323 (1945).

Hatai, T., T. Hashimoto and A. Ubukata : The blood mast cell of the tortoise (Abst., Japanese). Acta anat. nippon. 37 : 53-54 (1962).

Heath, I. D. : Staining of sulfated mucopolysaccharides. Nature 191 : 1370-1371 (1960).

Hunt, T. E. and E. A. Hunt : Blood basophiles of cockrels before and after intravenous injection of compound 48/80. Anat. Rec. $133: 19-33$ (1959). 
Juhlin, L. and W. B. Shelley : Detection of histamine by a new fluorescent o-phthalaldehyde stain. J. Histochem. Cytochem. 14 : 525-528 (1966).

Kahlson, G. and E. Rosengren : New approaches to the physiology of histamine. Physiol. Rev. 48: 155-196 (1968).

Lagunoff, D., M. Phillips and E. P. Benditt: The histochemical demonstration of histamine in mast cells. J. Histochem. Cytochem. 9: 534-541 (1961).

McManus, J. F. A. : Periodate oxidation technique. In : (ed. by) J. F. Danielli : General cytochemical methods. New York, Academic Press, 1961 (Vol. 2, p. 171-195).

Magath, T. B. and G. M. Higgins : The blood of the normal duck. Fol. haematol. 51: 230-241 (1934).

Michel, N. A. : The mast cells in lower vertebrates. Cellule 33 : 339-462 (1923).

Misrahy, G. A. : The metabolism of histamine and adenylic compound in the embryo. Amer. J. Physiol. 147: 462-470 (1946).

Ohuye, T. and $\mathbf{O}$. Ochi : Supplementary observations of the effects of splenectomy upon the newt, Triturus pyrrhogaster. Mem. Ehime Univ., Sec. II Ser. B (Biol.), 2 : 37-49 (1954).

Reite, O. B. : A phylogenic approach to the functional significance of tissue mast cell histamine. Nature 206 : 1334-1336 (1965).

Riley, J. F. and G. B. West : Histamine in tissue mast cells. J. Physiol. (London) 117, 72p (1952).

Romeis, B. : Mikroskopische Technik. 15. Auf1. München, Leipzig-Verlag, 1948 (p. 171).

Shelley, W. B., S. Öhman and H. M. Parnes : Mast cell stain for histamine in freeze-dried embedded tissue. J. Histochem. Cytochem. 16: 433-439 (1968).

Takaya, K. : A Bouin-lead acetate mixture for the cytological study of pancreatic islets in aldehyde fuchsin-trichrome stain. Arch. histol. jap. 27 : 569-575 (1966).

: Mast cells and histamine in a newt, Triturus pyrrhogaster Boié. Experientia $20: 1053-$ 1056 (1968).

Takaya, K., T. Fujita and K. Endo: Mast cells free of histamine in Rana catesbiana. Nature 215 : 776-777 (1967). 